\title{
Mechanism of Antifungal Action of Procymidone in Botrytis cinerea
}

\author{
Yoshio HISAdA*, Toshiro Kato* and Yasuo KAWASE* \\ 久田 芳夫*·加藤 寿郎*・川瀬 保夫* : プロサイミドンの灰色かび \\ 病菌に対する作用機構
}

\begin{abstract}
$N$-(3', 5'-dichlorophenyl)-1, 2-dimethylcyclopropane-1, 2-dicarboximide, procymidone (S-7131, Sumilex ${ }^{\circledR}$ ) inhibited increase in hyphal cell number of Botrytis cinerea preceding inhibition of increase of hyphal dry weight.

Oxygen consumption of the mycelium was hardly affected. Procymidone curtailed increase in protein, RNA and DNA contents at the rates approximately corresponding to that of inhibition of dry weight increase. The incorporation of ${ }^{3} \mathrm{H}$-uridine into acid-soluble and acid-insoluble fractions of the cells was more rapidly and strikingly inhibited. The effect on uridine incorporation may be ascribed to disturbance of membrane function for the transport. Procymidone moderately affected the incorporation of ${ }^{14} \mathrm{C}$-acetate into total lipids and did not specifically inhibit the synthesis of individual lipid class. The synthesis of the cell wall was stimulated by the treatment of procymidone without marked change in its constituents. Though the primary site of action of procymidone is still obscure, it is supposed that procymidone may act on cytoplasmic membrane and its action must be related to membrane function for the transport and cell wall synthesis.
\end{abstract}

(Received July 22, 1978)

\section{Introduction}

Procymidone (S-7131, Sumilex $\left.{ }^{\circledR}\right), N$ - $\left(3^{\prime}, 5^{\prime}\right.$-dichloro-phenyl) -1, 2-dimethylcyclopropane-1, 2-dicarboximide is an antifungal compound that is toxic to a number of phytopathogenic fungi, particularly Sclerotinia and Botrytis species ${ }^{10)}$. It has been also shown that procymidone has desirable properties such as curative and systemic action as a chemotherapeutic agent against plant diseases and effectively eradicates gray mould and Sclerotinia rot diseases of agricultural and horticultural crops in practical applicaton.

We investigated morphological effects of procymidone on Botrytis cinerea and found that the fungitoxicant caused swelling and bursting of the hyphal cells, suggesting its action on the cell membrane or cell wall ${ }^{9)}$. However, successful regeneration of the cell wall on the hyphal protoplasts in the presence of procymidon indicated that direct disintegration of the cell membrane and inhibition of the cell wall synthesis were improbable.

Dichlozoline $\left[3-\left(3^{\prime}, 5^{\prime}\right.\right.$-dichlorophenyl)-5,5-dimethyloxazolidine-2,4-dione $]$, iprodione [3-(3', $5^{\prime}$-dichlorophenyl)-1-isopropylcarbamoylimidazolidine-2,4-dione $]$ and vinchlozolin [3-( $3^{\prime}, 5^{\prime}$-dichlorophenyl)-5-methy1-5-vinyloxazolidine-2,4-dione $]$ are analogues of procy-

* Research Department, Pesticides Division Sumitomo Chemical Co., Ltd. Takarazuka, Hyogo, Japan, 住友化学工業株式会社農薬事業部研究部 
midone with simlar antifungal activity. They commonly have a cyclic $N$ - $(3,5-$ dichlorophenyl) imide in their chemical structures. Effects on fungal metabolism of the compounds of this group have been investigated. Buchenauer ${ }^{1)}$ showed in his preliminary study that vinchlozolin inhibited the incorporation of ${ }^{14} \mathrm{C}$-acetate into triglicerides in Ustilago avenae. Recently, iprodione and vinchlozolin were shown to cause remarkable inhibition of the incorporation of ${ }^{14} \mathrm{C}$-uridine into nucleic acids in $B$. cinerea $^{6}$. However, it is still vague if these inhibitions can be ascribed to the primary cause of the fungitoxicity of this group of fungicides and further investigations are needed.

The present study was undertaken as a part of research concerning the mode of fungitoxic action of procymidone and elucidated the cytological and biochemical events in $B$. cinerea associated with the growth inhibition by the fungitoxicant.

\section{Materials and Methods}

Culture Technique. The conidia of B. cinerea prepared as described previous1y9) were grown in a Sakaguchi flask containing the nutrient medium ${ }^{14}$ ) on a reciprocal shaker at $27 \mathrm{C}$. The initial concentration of the inoculum was $1 \times 10^{6}$ conidia per ml. Sixteen-hr old cultures were used throughout this work unless otherwise stated.

Fungicides and Chemicals. Procymidone in methanol was added to the cultures at a growth-inhibitory concentration of $20 \mu \mathrm{M}$; a final concentration of methanol was $0.2 \%$. Cycloheximide was purchased from P-L biochemicals inc. (Milwaukee, USA) and dissolved in methanol. L-Leucine-U-14 $\mathrm{C}(280 \mathrm{mCi} / \mathrm{mmol})$, uridine $-5 \cdot{ }^{3} \mathrm{H}(17.8 \mathrm{Ci} / \mathrm{mmol})$, uridine $-2-{ }^{14} \mathrm{C}(57 \mathrm{mCi} / \mathrm{mmol})$, sodium acetate $-1-{ }^{14} \mathrm{C}$ $(49.3 \mathrm{mCi} / \mathrm{mmol}), \quad$ D-glucose-U- ${ }^{1}{ }^{4} \mathrm{C}(101 \mathrm{mCi} / \mathrm{mmol})$ and D-glucosamine-1-1 ${ }^{4} \mathrm{C}$ (56.5 $\mathrm{mCi} / \mathrm{mmol}$ ) were obtained from Daiichi Pure Chemicals Co. (Tokyo, Japan).

Cytological Observation. Rectangular sheets of dialyzer tubings were placed on the surface of the nutrient agar medium and a drop of the conidial suspension was spread over their surface. After incubation for $12 \mathrm{hr}$ at $25 \mathrm{C}$, the sheets were removed into the liquid nutrient medium with or without procymidone and further incubated for appropriate periods. Helly fixation followed by staining with GiemsasLösung (E. Merck) after hydrolysis was carried out in the manner described by Davidse ${ }^{4)}$.

Respiratory Measurements. Oxygen uptake by the mycelium was measured in the presence or absence of procymidone by a conventional manometric technique using a Gilson differential respirometer.

RNA, DNA and Protein Analysis. Quantitative determinations of RNA, DNA and protein in the mycelium were made colorimetrically. Fifteen $\mathrm{ml}$ of the culture in a $100-\mathrm{ml}$ Erlenmeyer flask was incubated for various periods with procymidone or the solvent. The mycelia of duplicate samples of the treated or control cultures were collected by filtration and washed with distilled water. Each constituent in the filtrated mycelium was fractionated according to the method of Schmidt and Thanhauser ${ }^{19)}$. The amounts of RNA, DNA and protein were determined by the methods described previously $20,7,15$ ) with yeast RNA, calf thymus DNA and bovine albumin as a respective standard.

Incorporation of Radioactive Substrates. Radio-labeled leucine, uridine, acetate or glucose was added to $1-\mathrm{ml}$ cultures, which were incubated on a reciprocal shaker at $27 \mathrm{C}$, at various times after addition of procymidone.

In the test of leucine or uridine incorporation, the mycelium was filtered through a glass fiber paper (Whatman $\mathrm{GF} / \mathrm{C}$ ) after $20 \mathrm{~min}$ incorporation period and then 
washed with cold water. The filter with mycelium was immediately immersed in 5 $\mathrm{ml}$ of $5 \%$ trichloroacetic acid (TCA) and kept on ice at least for $1 \mathrm{hr}$ with occasional shakings. TCA-soluble and insoluble fractions were separated by filtration through the filter. Each fraction was assayed for radioactivity. In some experiments, the mycelia incubated with ${ }^{14} \mathrm{C}$-uridine in the presence or absence of procymidone were extracted with $5 \%$ perchloric acid (PCA), the filtrates were treated with charcoal (Norit A), and the absorbed nucleosides and nucleotides were subsequently eluted with $10 \%$ pyridine $^{23)}$. Pyridine was removed from the elute by extraction with chloroform. The aqueous layer was evaporated to dryness in vacuo. The residue was cochromatographed with the standard samples on a Toyo filter paper (No 51). The solvent systems in the first and second dimensions were isobutyric acidconcentrated $\mathrm{NH}_{4} \mathrm{OH}$-water $(57: 4: 39, \mathrm{v} / \mathrm{v})$ and methanol-1 $\mathrm{M}$ ammonium acetate $(7: 3$, $\mathrm{v} / \mathrm{v})$, respectively.

In the test of acetate incorporation into mycelial lipids, the reaction was terminated by adding $3.75 \mathrm{ml}$ of methanol-chloroform $(2: 1, \mathrm{v} / \mathrm{v})$ and the lipids were extracted by the method of Bligh and Dyer as modified by Kates ${ }^{13)}$. The extracts were evaporated to dryness in vacuo and thin layer chromatography (TLC) of the residues was carried out on a silica gel $\mathrm{F}_{254}$ precoated plate (E. Merck) using the solvent system of heptane-isopropyl ether- acetic acid (60:40:4, v/v) for neutral lipids and the solvent system of Nichols ${ }^{17)}$ for complex lipids.

Effects of procymidone on the incorporation of labeled acetate, leucine, glucose or glucosamine into the cell wall fraction were examined as follows. Each labeled substrate was added to $20 \mathrm{ml}$ cultures in $100 \mathrm{ml}$ conical flasks which were preincubated with or without procymidone for $60 \mathrm{~min}$ at $27 \mathrm{C}$ on a reciprocal shaker, and they were incubated for further $60 \mathrm{~min}$. The samples were chilled on ice immediately after the procedure and centrifuged. The collected mycelium was resuspended in a $0.2 \mathrm{M}$ phosphate buffer $(\mathrm{pH} 7.0)$ with acid-washed glass beads $(0.2 \mathrm{~mm}$ in diameter). The cells were broken by sonification using Sonifier (Branson, Model W185) at $130 \mathrm{~W}$ for $10 \mathrm{~min}$, then cooled for $2 \mathrm{~min}$, and moreover broken for $5 \mathrm{~min}$. After breakage, the cell walls were sedimented by centrifugation at $12,000 \mathrm{~g}$ for 10 min, suspended in a phosphate buffer, and sonicated further at $100 \mathrm{~W}$ for 2 min for removing cytoplasmic residues. The procedure was repeated three times in the buffer and four times in distilled water. A course of breakage was followed by a phase-contrast microscopy. A portion of the cell wall fraction was taken for determination of dry weight and the remaining was assayed for radioactivity.

Radioactivity was measured with a liquid scintillation spectrometer ${ }^{11)}$. Radioactive regions on TLC plates and papers were visualyzed by an autoradiographic technique.

Chemical Analysis of Cell Wall. Cell wall fractions were obtained from the mycelia, which were incubated for $6 \mathrm{hr}$ in the presence or absence of procymidone, by the Procedure described above. Lyophilized cell wall materials were extracted first with boiling diethyl ether and then with diethyl ether-ethanol-HCl (100:100:1, $\mathrm{v} / \mathrm{v})^{12)}$. Subsequently the residues were treated with $0.5 \mathrm{M}$ acetic acid for $30 \mathrm{~min}$ at $75 \mathrm{C}$. Following centrifugation, the pellets were extracted with $2 \mathrm{~N} \mathrm{NaOH}$ for $18 \mathrm{hr}$ at $37 \mathrm{C}, 1 \mathrm{~N} \mathrm{H}_{2} \mathrm{SO}_{4}$ for $16 \mathrm{hr}$ at $90 \mathrm{C}$, and $2 \mathrm{~N} \mathrm{NaOH}$ for $1 \mathrm{hr}$ at $37 \mathrm{C}$ in this order. After centrifugation, the pellets were lyophilized. Cell wall components in the alkali extracts were precipitated by addition of 2 volumes of ethyl alcohol, and the precipitates were dialized against distilled water and lyophilized. Acid-soluble fractions were neutralized with barium carbonate and centrifuged for removal of barium sulfate. The resultant supernatants were lyophilized. The polymers in each fraction were hydrolyzed in $3 \mathrm{~N} \mathrm{HCl}$ for $4 \mathrm{hr}$ at $95 \mathrm{C}$ and excess $\mathrm{HCl}$, after evaporation, was re- 
moved over $\mathrm{NaOH}$ pellets in vacuo. Cell wall hydrolysis products were separated by paper chromatography. Chromatograms were irrigated with ethyl acetate-pyridinewater $(8: 2: 1, \mathrm{v} / \mathrm{v})$ or ethyl acetate-acetic acid-pyridine-water $(5: 1: 5: 3, \mathrm{v} / \mathrm{v})$ and developed with alkaline $\mathrm{AgNO}_{3}$ reagent (reducing sugar) or ninhydrin (amino sugar). The lipid was measured by weight; contents of protein, neutral sugar and amino sugar were colorimetrically estimated ${ }^{15,2,18)}$; total acetyl content was determined after conversion of acetyl group to methyl acetate and subsequent distillation ${ }^{24)}$.

\section{Results}

\section{Effect on Growth}

During first $2 \mathrm{hr}$, dry weight increase of actively growing mycelium of $B$. cinerea continued at the same rate in the presence of procymidone as in the control but the inhibition became evident after $3 \mathrm{hr}$ (Fig. 1). After 6-8 hr, the rate of dry weight increase was inhibited by $86 \%$.

\section{Cytological Effect}

The effect on increase in cell and nucleus number per germ tube was examined by using $12 \mathrm{hr}$ cultures. $\mathrm{A}^{\mathrm{t}}$ this time, the doubling time of cell and nucleus number was about $4 \mathrm{hr}$. Table 1 represents the effect of procymidone on increase in cell number. Inhibition of dry weight increase was not noted during $2 \mathrm{hrc}$ inubation with procymidone; nevertheless, increase in hyphal cell number was prevented by $65 \%$. Also, increase in nucleus number was inhibited to a similar extent; that is, its increase

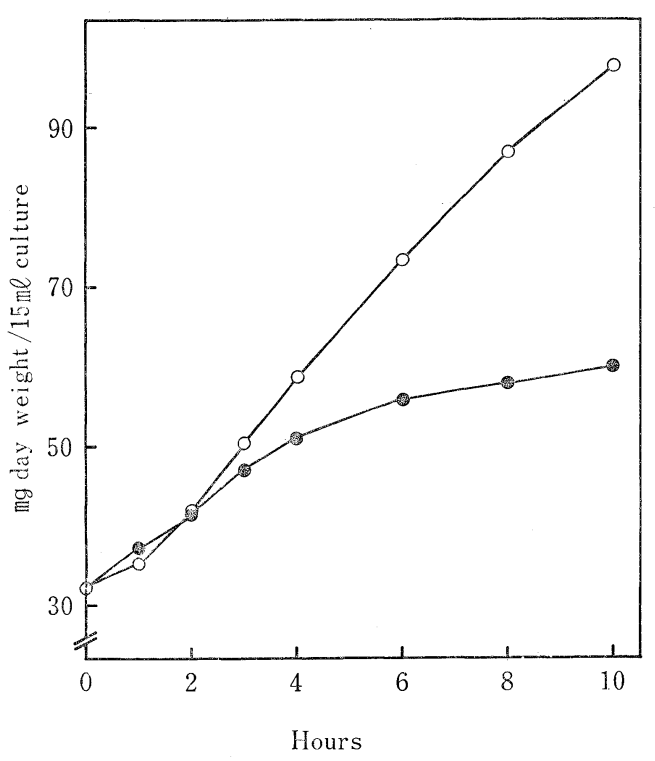

Fig 1. Effect of procymidone on dry weigt increase of $B$. cinerea. $\bigcirc$ : Control. : $20 \mu \mathrm{M}$ Procymidone per 200 germ tubes during a $2 \mathrm{hr}$ incubation period was 1,418 in the control and 390 in the treatment, respectively. Giemsa-HCl staining of the hyphae incubated in the presence of procymidone for 6 hr showed no morphologically abnormal nuclei in interphase or mitosis.

Table 1. Effect of procymidone on increase in cell number per germ tube of B. cinerea $a^{\text {a) }}$

\begin{tabular}{c|c|c|c}
\hline \hline & $\begin{array}{c}\text { Cell number/ } \\
400 \text { germ tubes }\end{array}$ & Increase in cell number & $\begin{array}{c}\text { mg Dry weight of } \\
\text { mycelium/culture }\end{array}$ \\
\hline $\begin{array}{c}\text { Control } \\
\text { procymidone } \\
20 \mu \mathrm{M}\end{array}$ & 1,522 & 510 & 71.5 \\
\hline
\end{tabular}

a) Cell number was measured after incubating 12-hr culture for $2 \mathrm{hr}$ in the presence or absence of procymidone. At the time of the treatment of the fungitoxicant, cell number per 400 germ tubes was 1,012 and $\mathrm{mg}$ dry weight of mycelium per $30-\mathrm{ml}$ culture was 47.0 . 


\section{Effect on Respiration}

Respiration of young mycelium of B. cinerea was hardly reduced by procymidone at a growth-inhibitory concentration. Oxygen consumption during a $2.5 \mathrm{hr}$ incubation period following $20 \mathrm{~min}$ preincubation with procymidone was $316 \mu 1 / \mathrm{mg}$ dry weight of the mycelium in the control and $302 \mu 1$ in the treatment. Failure of procymidone to affect respiration of $B$. cinerea even after a long exposure to the fungitoxicant demonstrates that inhibition of growth is not due to interference with energy production.
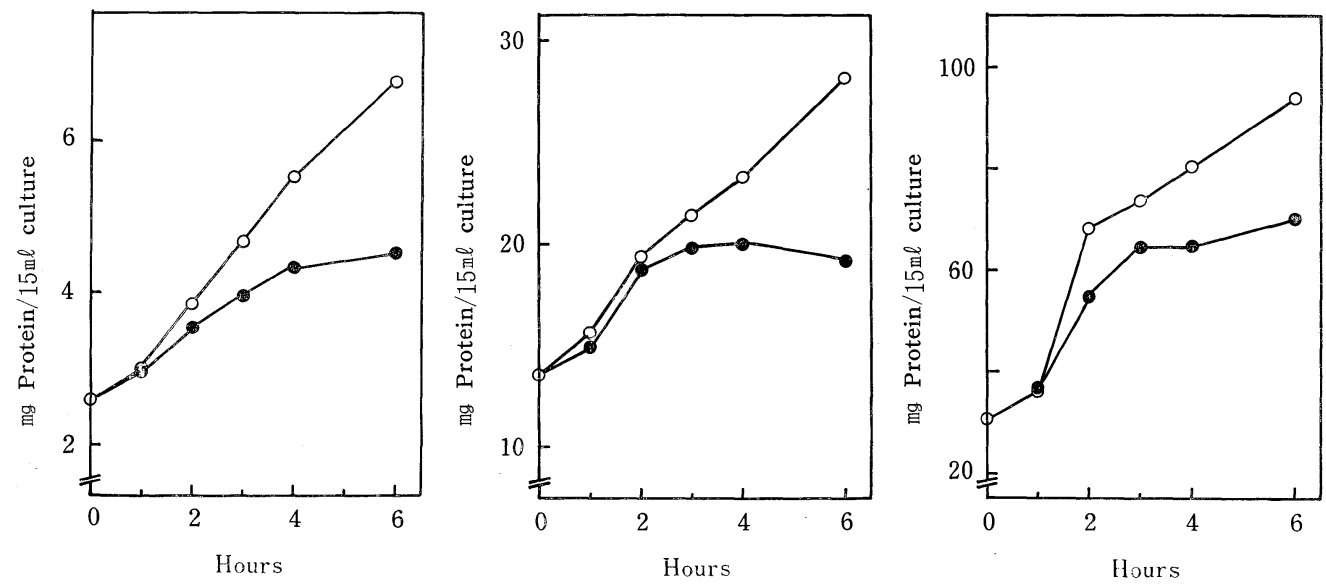

Fig 2. Effect of procymidone on increase in protein, RNA and DNA contents in B. cinerea. $\bigcirc:$ Control, $: 20 \mu \mathrm{M}$ Procymidone

\section{Effect on Syntheses of Cellular Constiuiunts}

The effects on syntheses of cellular constituents in the mycelium of $B$. cinerea were examined by colorimetric measurements of the total amounts and by measuring the incorporations of radioactive substrates. Inhibition of increase in protein, RNA and DNA contents in mycelial cells simultaneously occurred nearly $2 \mathrm{hr}$ after addition of procymidone (Fig. 2 ). Thereafter the rates of increase in RNA and DNA contents progressively declined in the treated cells. Increase of protein was completely arrested about $3 \mathrm{hr}$ after the treatment. Two to $3 \mathrm{hr}$ after the treatment of procymidone, hyphal cells of $B$. cinerea partially started bursting ${ }^{9)}$. Therefore, some cellular constituents may be lost from the hyphae towards these incubation times.

Table 2. Effect of procymidone on rates of the incorporation of ${ }^{14} \mathrm{C}$-leucine into both acid-soluble and acid-insoluble fractions of hyphal cells of $B$. cinere $^{\text {a) }}$

\begin{tabular}{|c|c|c|c|c|c|c|}
\hline \multirow{3}{*}{$\begin{array}{l}\text { Incorporation } \\
\text { periods after } \\
\text { treatment } \\
\quad(\text { min })\end{array}$} & \multicolumn{6}{|c|}{ Incorporated radioactivity (cpm/culture) } \\
\hline & \multicolumn{3}{|c|}{ Acid-soluble fraction } & \multicolumn{3}{|c|}{ Acid-insoluble fraction } \\
\hline & Control & $\begin{array}{c}\text { Procymidone } \\
20 \mu \mathrm{M} \\
\end{array}$ & $\begin{array}{c}\text { Cyclohexi mide } \\
10 \mu \mathrm{g} / \mathrm{ml}\end{array}$ & Control & $\begin{array}{c}\text { Procymydone } \\
20 \mu \mathrm{M} \\
\end{array}$ & $\begin{array}{c}\text { Cycloheximide } \\
10 \mu \mathrm{g} / \mathrm{ml}\end{array}$ \\
\hline $0-20$ & 3,670 & 3,423 & - & 47,518 & 36,948 & - \\
\hline $20-40$ & 6,048 & 5,889 & - & 94,708 & 54,110 & - \\
\hline $40-60$ & 6,776 & 14,097 & 18,592 & 94,669 & 70,759 & 3,832 \\
\hline $100-120$ & 7,769 & 23,914 & 13,274 & 173,473 & 103,924 & 4,119 \\
\hline $160-180$ & 6,201 & 33,305 & 27,515 & 294,559 & 180,858 & 4,325 \\
\hline
\end{tabular}

a) $0.5 \mu \mathrm{Ci}$ of ${ }^{14} \mathrm{C}$-leucine was added to $1 \mathrm{ml}$ of culture. 
Immediate inhibition after the treatment was observed in the incorporation of ${ }^{14} \mathrm{C}$-leucine into the acid-insoluble materials (Table 2). The rate of inhibition was $43 \%$ after $40 \mathrm{~min}$ incubation and then slightly diminished. With a little time lag, radioactivity accumulated in the acid-soluble fraction. In the same series of experiments, cycloheximide extremely inhibited the incorporation of ${ }^{14} \mathrm{C}$-leucine into the acid-insoluble fraction and induced a concomitant accumulation of radioactivity in the intracellular pool. Procymidone markedly curtailed the incorporation of ${ }^{3} \mathrm{H}$-uridine into both acidsoluble and insoluble fractions after $40 \mathrm{~min}$ incubation (Fig. 3). Afterwards, its inhibitory effect temporalily became loose similarly to the effect on the incorporation of leucine into the acidinsoluble materials. Such partial recoveries from inhibition are difficult to explain at present. More inhibition of the incorporation into DNA than into RNA was recognized by fractionation of the acid-insoluble fractions (Table 3). Further investigation of the acid-soluble metabolites of ${ }^{14} \mathrm{C}$-uridine indicated that procymidone did not specifically inhibit the process synthesizing nucleotides from uridine (Table 4). Data of uridine incorporation suggest the
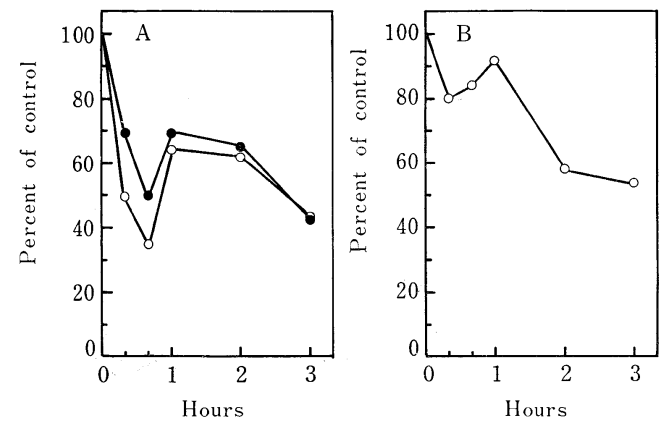

Fig 3. Effect of procymidone on rates of the incorporation of ${ }^{3} \mathrm{H}$-uridine into both acid-soluble (O) and acid-insoluble (O) (A) and ${ }^{14} \mathrm{C}$-acetate into total lipids in $B$. cinerea (B). One $\mu \mathrm{Ci}$ of ${ }^{3} \mathrm{H}$-uridine or ${ }^{14} \mathrm{C}$-acetate was added to $1 \mathrm{ml}$ of culture. Each plotted point represents measurement for 20 min incorporation before the time when the point indicates. possible affection on a membrane function for the transport. However,

Table 3. Effect of procymidone on rates of the incorporation of ${ }^{3} \mathrm{H}$-uridine into nucleic acids in hyphal cells of $B$. cinerea $a^{\text {a) }}$

\begin{tabular}{|c|c|c|c|c|}
\hline \multirow{3}{*}{$\begin{array}{l}\text { Incorporation } \\
\text { periods after } \\
\text { treatment } \\
\text { (min) }\end{array}$} & \multicolumn{4}{|c|}{ Incorporated radioactivity $(\mathrm{cpm})$} \\
\hline & \multicolumn{2}{|c|}{ RNA fraction } & \multicolumn{2}{|c|}{ DNA fraction } \\
\hline & Control & $\begin{array}{l}\text { Procymidone } \\
20 \mu \mathrm{M}\end{array}$ & Control & $\begin{array}{c}\text { Procymidone } \\
20 \mu \mathrm{M}\end{array}$ \\
\hline $0-20$ & 97,083 & 66,528 & 508 & 340 \\
\hline $20-40$ & 140,364 & 71,589 & 748 & 316 \\
\hline $40-60$ & 129,591 & 81,354 & 628 & 340 \\
\hline $100-120$ & 133,224 & 110,628 & 648 & 432 \\
\hline
\end{tabular}

a) Two $\mu \mathrm{Ci}$ of ${ }^{3} \mathrm{H}$-uridine was added to $1 \mathrm{ml}$ of culture.

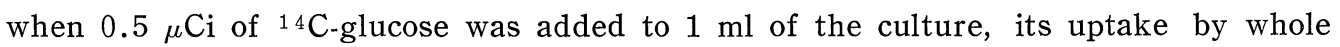
cells was not prevented. The ratio of the radioactivity incorporated into the treated cells to that into the control cells was 1.04 during a incubation period of 160-180 $\min$.

Procymidone slightly prevented the incorporation of ${ }^{14} \mathrm{C}$-acetate into total lipids until 60-min incubation time and thereafter significantly (Fig. 3). The incorporation 
Table 4. Effect of procymidone on the incorporation of ${ }^{14} \mathrm{C}$-uridine into acid-soluble metabolites in hyphal cells of $B$. cinerea ${ }^{\text {a) }}$

\begin{tabular}{l|r|r|r}
\hline \multirow{2}{*}{ Metabolite } & \multicolumn{2}{|c|}{ Radioactivity (cpm) } & Inhibition $(\%)$ \\
\cline { 2 - 3 } & Control & Treated & 66 \\
Uridine & 2,686 & 909 & 85 \\
UMP & 73,074 & 10,880 & 76 \\
UDP & 53,602 & 13,028 & 84 \\
UTP & 5,147 & 846 & 85 \\
Unknown I & 1,831 & 266 & 80 \\
Unknown II & 47,909 & 9,739 & 81 \\
Total & 184,549 & 35,773 & \\
\hline
\end{tabular}

a) Five $\mu \mathrm{Ci}$ of ${ }^{14} \mathrm{C}$-uridine was added to $1 \mathrm{ml}$ of culture. The mycelium was extracted with perchloric acid after a 20 -min incorporation period following 20 -min preincubation with or without $20 \mu \mathrm{M}$ of procymidone.

Table 5. Effect of procymidone on the incorporation of radioactive substrates into cell wall fraction of hyphal cells of B. cinerea a)

\begin{tabular}{l|c|c|c}
\hline \multirow{2}{*}{ Substrate } & \multicolumn{2}{|c|}{$\begin{array}{c}\text { Incorporated radioactivity } \\
\text { (cpm/mg dry weight) }\end{array}$} & Percent of con trol \\
\cline { 2 - 3 } & Control & Treated & 349 \\
\hline Acetate-1-14C & 199 & 694 & 142 \\
D-Glucose-U-14C & 525 & 744 & 176 \\
D-Glucosamine-1-14C & 1,037 & 1,825 & 102 \\
Leucine-U-14C & 1,016 & 1,041 &
\end{tabular}

a) Cell wall fraction was obtained from the mycelium which was incubated with radioactive substrates for $60 \mathrm{~min}$ following 60 -min preincubation with or 20 $\mu \mathrm{M}$ of procymidone.

of radioactivity into individual lipid class was not specifically inhibited.

Table 5 shows radioactivities incorporated into cell wall fractions during a 60 min incubation period with $2 \mu \mathrm{Ci}$ of ${ }^{14} \mathrm{C}$-glucose, ${ }^{14} \mathrm{C}$-glucosamine, ${ }^{14} \mathrm{C}$-acetate or ${ }^{14} \mathrm{C}$ leucine following 60 min preincubation with procymidone. Procymidone accelerated the incorporations of glucose, glucosamine and especially acetate into the cell wall fraction. Stimulation of acetate incorporation was evident $1 \mathrm{hr}$ after the treatment of procymidone, and reached maximum after $4 \mathrm{hr}$ (5.2-fold of the control).

Table 6. Effect of procymidone on the composition of hyphal cell wall of $B$. cinerea

\begin{tabular}{l|c|c}
\hline \multirow{2}{*}{ Component } & Percent of the cell wall dry weight \\
\cline { 2 - 3 } & Control & $\begin{array}{c}\text { procymidone } \\
20 \mu \mathrm{M}\end{array}$ \\
\hline Lipid & 1.20 & 1.15 \\
Bound lipid & 0.25 & 0.35 \\
Protein & 5.25 & 4.70 \\
Neutral sugar & 88.20 & 75.00 \\
Hexosamine & 2.34 & 3.09 \\
Acetyl & 0.7 & 1.2 \\
Recovery & 97.94 & 93.76 \\
\hline
\end{tabular}

a) The cell wall was prepared from the mycelium incubated for $6 \mathrm{hr}$ with or without $20 \mu \mathrm{M}$ of procymidone. 


\section{Effect on Cell Wall Synthesis}

Increase in the cell wall dry weight was $227 \mathrm{mg}$ in the control and $332 \mathrm{mg}$ in the treatment during a $6 \mathrm{hr}$ incubation period, while increases in mycelial dry weight were $1,274 \mathrm{mg}$ and $572 \mathrm{mg}$, respectively. Thus, procymidone-treatment enhanced synthesis of the cell wall in the mycelium despite growth inhibition. Table 6 gives the amounts of the various compounds in the cell wall. The treatment with procymidone slightly increased contents of hexosamine and acetyl residues, but decreased content of neutral sugar. To determine the effects on the syntheses of wall polymers, the cell wall was fractionated to yield four fractions according to the solubility, and each fraction was further analyzed for the composition by paper chromatography after acid hydrolysis (Table 7 ). Wall polysaccharides and their composition in the treated mycelium was similar to that in the control mycelium.

Table 7. Effect of procymidone on the synthesis of wall polymers of hyphal cells of $B$. cinerea

\begin{tabular}{l|c|c|l}
\hline \hline \multirow{2}{*}{\multicolumn{1}{c|}{ Fraction }} & Percent of total wall recovered & Main conponents \\
\cline { 2 - 3 } & Control & $\begin{array}{c}\text { Procymidone } \\
20 \mu \mathrm{M}\end{array}$ & \\
\hline Alkali-soluble & 25.8 & 26.6 & Glucose \\
Acid-soluble & 56.8 & 52.9 & Glucose, Galactose \\
Acid-resistant and alkali-soluble & 10.0 & 11.0 & Mannose, Glucosamine \\
Residue & 7.4 & 9.5 & Glucose \\
\hline
\end{tabular}

\section{Discussion}

Increase in hyphal nucleus number was depressed by $72 \%$ during $2 \mathrm{hr}$ incubation with procymidone, but the rate of this depression was similar to that of increase in cell number. Additionally, we could not find abnormal nuclei in interphase or mitosis. In cases of benomyl and griseofulvin, the fungitoxicity of which is ascribed to a failure of normal mitosis ${ }^{5)}$, abnormal nuclei or chromatins were photomicroscopically observed in the treated mycelial cells ${ }^{3,4,8)}$. These facts indicate few possibility that procymidone may primarily interfere with the process of nuclear division.

It is readily conceivable that procymidone acts at the lipophilic site on or in a cell because of its lipophilic property. The effect of procymidone on lipid synthesis was examined by incorporation of ${ }^{14} \mathrm{C}$-acetate into lipid classes in hyphal cells. Delayed inhibition of the incorporation of ${ }^{14} \mathrm{C}$-acetate into total lipid fraction and non-specific inhibition of the incorporation into individual lipid class suggest that it may be not the primary cause of the toxicity.

In the experiments on protein and nucleic acids syntheses, the incorporation of ${ }^{3} \mathrm{H}$-uridine and ${ }^{14} \mathrm{C}$-leucine into the acid-insoluble fraction was more rapidly inhibited by procymidone than would be expected from the results of chemical assay. It may be ascribed to retardation of the transport from an exogenous source into the cell. But affection on the membrane function for the transport would not be primarily responsible for growth inhibition, because the uptake of glucose into whole cells was not affected by procymidone at all. The incorporation of uridine into the acid-soluble fraction was most sensitive to procymidone-treatment, but further analysis of the radioactive metabolites in this fraction showed that procymidone did not primarily inhibit uridine metabolism. 
Procymidone stimulated synthesis of the cell wall although the fungitoxicant did not markedly change its constituents. It seems that this effect is produced by unbalanced metabolism in the cells treated with procymidone or alteration of the membrane on which the cell wall was constructed. Similarly to procymidone action on wall synthesis, cycloheximide, an inhibitor of protein synthesis ${ }^{21}$ induced wallthickening in hyphal cells of Aspergillus nidulans ${ }^{22)}$. S-1358, which specifically inhibited biosynthesis of ergosterol as a membrane sterol, stimulated the incorporation of ${ }^{14} \mathrm{C}$-acetate into the cell wall fraction in Monilinia fructigena ${ }^{14)}$. These fungitoxicants might affect wall synthesis secondarily as a result of inhibition of synthesis of membrane constituents. Procymidone remarkably inhibited the division of cells of young hyphae preceding inhibition of dry weight increase. This inhibition was accompanied by cessation of hyphal extension and swelling and bursting of hyphal cells. Thus, stimulation of cell wall synthesis must be connected with the proceedings of these morphological changes.

Though no direct evidences indicating the site primarily responsible for toxicity of procymidone in B. cinerea are obtained, aplausible conclusion from the available data is that the site of action may be on the cytoplasmic membrane. Partial disturbance of membrane permeability, stimulation of cell wall synthesis, and morphological abnormality due to procymidone lead to this conclusion, because these effects can be commonly attributed to the change of the membrane function. In this case, action mechanism of procymidone must be distinguishable from that of wellknown membrane toxicants such as polyene antibiotics and surface-active fungicides which inhibited the oxidation of glucose due to leakage of cellular constituents $^{16)}$. Many integral proteins with different functions are embeded in phospholipid bilayer of the membrane and represent the possible site of antifungal action. Also, it is likely that adsorption of procymidone to the cell membrane results in conformational alteration of the membrane which causes ultimate abnormalities.

\section{Literature cited}

1. Buchenauer H. (1976) Med. Fac. Landbouww. Rijksuniv. Gent $41: 1509-1519$.

2. Chung C. W. and W. J. Nickerson (1954) J. Biol. Chem. $208: 395$.

3. Crackower S. H. B. (1972) Can. J. Microbiol. $18: 683-687$.

4. Davidse L. C. (1973) Pestic. Biochem. Physiol. $3: 317-325$.

5. Dekker J. (1977) In Antifungal Compounds (M, R. Siegel and H. D. Sisler eds.) Marcel Dekker, Inc. New York, pp. 365-398.

6. Fritz R., P. Leroux and M. Gredt (1977) Phytopath. Z. $90: 152-163$.

7. Giles K. W. and A. Myers (1965) Nature 206: 93.

8. Gull K. and A. P. J. Trinci (1973) Ibid. $244: 292-294$.

9. Hisada Y. and Y. Kawase (1977) Ann. Phytopath. Soc. Japan $43: 151-158$.

10. Hisada Y., K. Maeda, N. Tottori and Y. Kawase (1976) J. Pesticide Sci. 1 : 145-149.

11. Hisada Y., K. Maeda, Y. Kawase and J. Miyamoto (1976) Ibid. 1 : 201-206.

12. Johnston I. R. (1965). Biochem. J. $96: 651-658$.

13. Kates M. (1972) Techniques of Lipidology, North Holland Publishing Company, Amsterdam.

14. Kato T. (1975) Dr. Thesis, Kyushu University, Kyushu, Japan.

15. Lowry O. H., N. J. Rosebrough, A. L. Farr and R. J. Randall (1951) J. Biol. Chem. 193 : 265-275.

16. Lukens R. J. (1971) Chemistry of Antifungal Action, Springer-Verlag, New York, pp. 41-44.

17. Nichols B. W. (1964) In Metabolism and physiological Significance of Lipids (R. M. C. Dawson and D. N. Rhodes $e d s$.) John Wiley and Sons, Ltd. London, pp. 635.

18. Rondle C. J. M. and W. T. J. Morgan (1955) Biochem. J. 61:586-589.

19. Schmidt G. and S. J. Thanhauser (1945) J. Biol. Chem. 161:83-89. 
20. Shneider W. C.(1957). In Methods in Enzymology $3:$ pp. 680 (S. P. Colowick and N. O. Kaplan eds.) Academic Press, New York.

21. Siegel M. R. (1977) In Antifungal Compounds (M. R. Siegel and H. D. Sisler eds.) Marcel Dekker, Inc. New York, pp. 399-438.

22. Sternlicht E., D. Katz and R. F. Rosenberger (1973) J. Bacteriol. $114: 819-823$.

23. Tsuboi K. K. and T. D. Price (1959) Arch. Biochem. Biophys. $81: 223-237$.

24. Work E. (1971) In Methods in Microbiology 5A:pp. 361 (J. R. Norris and D. W. Ribbons eds.) Academic Press, New York.

和 文 摘 要

\author{
プロサイミドンの扊色かび病菌に対する作用機構 \\ 久田 芳夫・加藤 寿郎・川瀬 保夫
}

\begin{abstract}
殺菌剂プロサイミドン（S-7131，スミレックス®）は，灰色かび病菌（Botrytis cinerea）の菌系細胞数 の増加を処理後直ちに抑えたが，菌体乾重は薬剤の存在下でもしばらく対照と同様に増加し，処理 3 時間後 頃からその阻害が明瞭となった。菌体の代謝活性に対するプロサイミドンの作用を検討したととろ，呼吸は 殆んど影響されなかった。菌体中の蛋白，RNA および DNA 量の増加は阻害されたが，その程度はいずれも 菌体乾重増加の抑制とほぼ一致した。 ${ }^{3} \mathrm{H}$-ウリジンの酸可溶性分画および不溶性分画への取り込みは初期に, しかも強く阻害された。この阻害は, プロサイミドンが細胞膜の透過機能に影響を与え, 生じているものと 推定された。 ${ }^{14} \mathrm{C}$-酢酸の全脂質への取り込みに対する阻害は弱く，また特定の脂質への取り込みを選択的に 阻害することあなかった。プロサイミドンは細胞壁の合成を著しく促進した。しかし，薬剤の存在下で合成 された細胞壁の構成成分に特に変化は認められなかった。B. cinereaにおいて，プロサイミドンの第一次作 用点はまだ明確でないが，プロサイミドンは細胞膜に何らかの作用をし，その結果として膜の透過機能や細 胞壁合成に影響を及ぼしていると考えられた。
\end{abstract}

